\title{
ANALISIS STRATEGI PEMASARAN PRODUK DENGAN METODE MOORA
}

\author{
${ }^{1}$ Gortap Lumbantoruan ${ }^{凶},{ }^{2}$ Eva Julia Gunawati Harianja \\ ${ }^{1}$ Program Studi Komputerisasi Akuntansi, Universitas Methodist Indonesia, Medan, Indonesia \\ ${ }^{2}$ Program Studi Manajemen Informatika, Universitas Methodist Indonesia, Medan, Indonesia \\ Email: lumbantoruan.gortap@,gmail.com
}

DOI: https://doi.org/10.46880/jmika.Vol4No2.pp114-119

\begin{abstract}
Multi - Objective Optimization On The Basis Of Ratio Analysis or often referred to as the MOORA method is a method that is often used as a method of decision making that uses optimization techniques to solve complex problems that have many criteria or multi-criteria. The MOORA method has the ability to separate various factors by separating the subjective part of the factors into several decision-making attributes by forming a decision matrix. The decision matrix will be normalized and optimized for each criterion to produce a preference value that can be used as a decision making. This method separates the criteria values that have different characteristics, namely criteria with benefit characteristics (beneficial) from criteria with cost characteristics (not profitable). In this study, an analysis using the MOORA method was carried out on the right product marketing strategy based on various factors, both factors originating from internal and external factors with the aim of determining the strategy that the company will implement in marketing products so that the company has a competitive advantage for win the market from competitors. The results of the analysis show that the differentiation strategy has a higher preference value, namely 56.576497 and the cost leadership strategy with a value of 54.790304 and market segmentation strategies with a value of 53.206742 .
\end{abstract}

Keyword: MOORA, Marketing Strategy, Competitive Advantage, Preference Value.

\begin{abstract}
ABSTRAK
Multi - Objective Optimization On The Basis Of Ratio Analysis atau sering disebut dengan metode MOORA merupakan metode yang sering digunakan sebagai metode pengambilan keputusan yang menggunakan teknik optimasi untuk menyelesaikan masalah kompleks yang memiliki banyak kriteria atau multi-kriteria. Metode MOORA memiliki kemampuan untuk pemisahan berbagai faktor dengan cara memisahkan bagian subjektif dari faktor-faktor kedalam beberapa atribut pengambilan keputusan dengan membentuk matriks keputusan. Matriks keputusan tersebut akan dinormalisasi dan dilakukan optimalisasi untuk setiap kriteria hingga menghasilkan nilai preferensi yang dapat dijadikan pengambilan keputusan. Metode ini memisahkan nilai kriteria yang memiliki sifat yang berbeda yaitu kriteria dengan sifat benefit (menguntungkan) dengan kriteria dengan sifat cost (tidak menguntungkan). Pada penelitian ini, dilakukan analisis dengan metode MOORA terhadap strategi pemasaran produk yang tepat berdasarkan berbagai faktor, baik faktor yang bersumber dari internal maupun faktor yang bersumber dari eksternal perusahaan dengan tujuan untuk menentukan strategi yang akan diterapkan perusahaan dalam memasarkan produk sehingga perusahaan memiliki keunggulan kompetitif untuk memenangkan pasar dari pesaing. Hasil analisis menunjukkan bahwa differentiation strategy memiliki nilai preferensi yang lebih tinggi yaitu 56,576497 dan cost leadership strategy dengan nilai 54,790304 serta market segmentation strategies dengan nilai 53.206742 .
\end{abstract}

Kata Kunci: MOORA, Strategi Pemasaran, Keunggulan Kompetitif, Nilai Preferensi.

\section{PENDAHULUAN}

Strategi pemasaran merupakan hal yang harus diperhatikan perusahaan-perusahaan dalam memasarkan produknya. Persaingan ketat antar pelaku bisnis untuk memenangkan pasar dari perusahaan yang sejenis membutuhkan strategi yang handal. Perusahaan berlomba membangun keunggulan kompetitif produk untuk menghasilkan nilai bagi konsumen. Keunggulan kompetitif diciptakan untuk berbeda dari perusahaan lain dengan tujuan mempengaruhi pelanggan agar memilih barang atau jasa yang ditawarkan perusahaan dibanding memilih barang atau jasa milik perusahaan saingan (Hernanti, Waluyo, \& Izzhati, 2017).

Memilih strategi pemasaran yang tepat dapat mempengaruhi keberlangsungan bisnis perusahaan. Kesuksesan perusahaan memenangkan persaingan pasar dari perusahaan yang menawarkan produk 
sejenis, sangat erat kaitannya dengan kualitas produk, harga, brand, dan juga yang tidak kalah penting adalah strategi pemasaran yang diterapkan. Diperlukan pemilihan strategi pemasaran yang cepat dan tepat sasaran sehingga akan memberikan keuntungan dan menjaga kelangsungan bisnis perusahaan. Memilih strategi pemasaran dipengaruhi berbagai faktor baik faktor yang berasal dari internal maupun faktor yang berasal dari eksternal perusahaan (Mayang Sari, Santoso, \& Hamdala, 2014).

Penentuan strategi pemasaran menjadi fokus dalam bidang penelitian saat ini. Berbagai penelitian yang telah dilakukan seperti yang dilakukan oleh Hernanti et al. (2017) melakukan penelitian tentang strategi pemasaran yang paling baik yang diterapkan pada PT. Astra International TBK. Budiwaluyo \& Setiyaningsih (2015) memprediksi pemasaran penjualan mobil berdasarkan kebutuhan pelanggan. Sianturi (2015) menganalisis kebijakan promosi kampus menggunakan metode profile matching. Gusman, Verdian, \& Efnita (2017) menggunakan fuzzy logic dalam menentukan strategi pemasaran. Sugiarti et al. (2018) menggunakan metode weighted aggregated sum product assesment untuk penentuan kebijakan strategi promosi dan Utsalina \& Dewa (2017) menggunakan kombinasi metode SWOT dan AHP untuk menentukan strategi pemasaran.

Pemilihan strategi pemasaran melibatkan banyak atribut yang dipengaruhi oleh berbagai faktorfaktor subjektif serta membutuhkan langkah-langkah yang tepat sehingga dibutuhkan metode yang dapat mengkonversi penilaian subjektif dan dapat memberikan nilai kompetitif bagi perusahaan. Salah satu metode pengambilan keputusan yang dapat menyelesaikan permasalahan yang memiliki banyak atribut adalah Multi - Objective Optimization On The Basis Of Ratio Analysis atau sering disebut dengan metode MOORA. Dalam proses analisisnya, MOORA menggunakan teknik optimasi multi-kriteria untuk menyelesaikan berbagai permasalahan yang kompleks atau rumit terkait pengambilan keputusan. Keunggulan metode ini adalah memiliki kemampuan untuk memisahkan bagian subjektif dari faktor-faktor kedalam beberapa kelompok atribut yang digunakan dalam pengambilan keputusan.

Dengan menerapkan metode MOORA diharapkan dapat membantu perusahaan dalam memilih strategi pemasaran berdasarkan fakta-fakta lapangan secara objektif sehingga akan menambah nilai kompetitif perusahaan dan memenangkan persaingan pasar.

\section{TINJAUAN PUSTAKA}

\section{Strategi Pemasaran}

Strategi pemasaran adalah suatu proses merancang dan menganalisa pasar serta mengimplementasikan rancangan yang didasarkan pada rencana yang menyeluruh, terpadu dengan tujuan tercapainya pemasaran suatu perusahaan sesuai dengan target-target yang telah ditentukan. Strategi pemasaran memiliki sasaran, kebijakan dan aturan serta respon atas perubahan pola konsumsi masyarakat yang berubah dan pola atau keadaan persaingan antar perusahaan yang memiliki produk sejenis (Hakim \& Faizah, 2018).

Strategi pemasaran yang dapat dilaksanakan dalam membangun keunggulan kompetitif agar perusahaan dapat bersaing adalah sebagai berikut (Jannah, 2014):

1. Cost Leadership Strategy

Strategi pemasaran ini menjadikan harga produk yang ditawarkan lebih murah dari harga produk yang ditawarkan perusahaan lain dengan mengurangi biaya merugikan keuangan perusahaan.

\section{Differentiation Strategy}

Strategi ini merupakan strategi dimana perusahaan menciptakan suatu produk yang unik yang tidak dimiliki perusahaan lain.

3. Market Segmentation Strategies

Strategi ini mengklasifikasikan target pasar kedalam segmen yang lebih kecil atau spesifik dan memfokuskan produksi dan pemasaran untuk pasar dengan segmen tersebut.

Aspek kriteria yang sering digunakan dalam memilih strategi yang akan digunakan dalam pemasaran meliputi aspek kapabilitas manajerial, kapabilitas menjaga pelanggan, kapabilitas berinovasi, kapabilitas distribusi, aset sumber daya manusia, dan reputasi (Arvianto, Sari, \& Olivia, 2014).

\section{Metode MOORA}

MOORA atau Multi - Objective Optimization On The Basis Of Ratio Analysis pertama kali dikenal luas oleh dunia setelah digagas oleh dua ilmuwan Brauers dan Zavadkas. Ilmuwan tersebut menggagas metode ini untuk pengambilan keputusan yang terdiri dari beberapa kriteria atau multi-kriteria. Metode MOORA bekerja dengan mengelompokkan nilai kriteria yang berbeda sifat yaitu kriteria yang bersifat benefit (menguntungkan) dengan kriteria yang bersifat cost (tidak menguntungkan) (Manurung, 2018).

Penyelesaian masalah dalam pengambilan keputusan menggunakan metode MOORA didasarkan 
pada langkah-langkah berikut (Hasanah, Parlina, \& S.Sitio, 2019; Wardani, Parlina, \& Revi, 2018):

Langkah 1: Pembentukan matriks keputusan

Membentuk matriks berdasarkan nilai alternatif yang diberikan untuk setiap kriteria

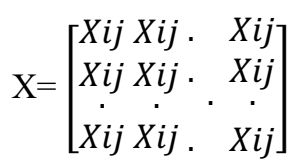

$$
\begin{aligned}
& \text { Keterangan: } \\
& \text { X } \quad \text { : Matriks X } \\
& \text { i } \quad \text { alternatif ke-i } \\
& \text { j } \quad: \text { kriteria ke-j }
\end{aligned}
$$

Langkah 2: Normalisasi matriks.

Melakukan normalisasi terhadap matriks keputusan yang dibuat sebelumnya dengan cara membagi nilai altenatif dengan akar dari jumlah nilai alternatif untuk setiap kriteria.

$$
X i j=\frac{X i j}{\sqrt{\sum_{j=1}^{m} x_{i j}^{2}}}
$$

Keterangan:

$$
\begin{array}{ll}
\mathrm{x}_{\mathrm{ij}} & \text { : alternatif } \mathrm{i} \text { untuk kriteria } \mathrm{j} \\
\mathrm{i} & : \text { alternatif ke-i } \\
\mathrm{j} & : \text { kriteria ke- } \mathrm{j}
\end{array}
$$

Langkah 3: Optimalisasi atribut

Mengurangkan nilai kriteria yang memiliki sifat benefit dengan nilai kriteria cost untuk setiap kriteria

$$
Y i=\sum_{j=1}^{g} W j X i j-\sum_{j=g+1}^{n} W j X i j
$$

$$
\begin{array}{ll}
\text { Keterangan } \\
\mathrm{i} \quad \text { : alternatif ke-i } \\
\mathrm{j} \quad \text { : kriteria ke- } \mathrm{j} \\
\mathrm{X} & \text { : nilai normalisasi } \\
\mathrm{W}_{\mathrm{j}} & \text { : bobot setiap kriteria } \\
\mathrm{y}_{\mathrm{i}} & \text { : nilai preferensi tiap alternatif }
\end{array}
$$

Langkah 4: Menentukan nilai preferensi dan rangking Nilai Yi merupakan hasil dari optimalisasi atribut berupa bilangan yang jumlahnya tergantung dari jumlah kriteria yang bersifat benefit (kriteria yang menguntungkan) dan jumlah kriteria yang bersifat cost (kriteria yang tidak menguntungkan) dalam matriks keputusan. Dimana nilai Yi tertinggi merupakan strategi pemasaran yang terbaik.

\section{METODE PENELITIAN}

\section{Alur Penelitian}

Langkah-langkah penyelesaian masalah dalam analisis stategi pemasaran produk menggunakan metode MOORA dapat dilihat seperti flowchart berikut ini:

1. Pembentukan dan klasifikasi kriteria, bobot masing-masing kriteria, dan alternatif serta memberi nilai kriteria untuk masing-masing alternatif.

2. Membentuk matriks keputusan berdasarkan nilai alternatif untuk setiap kriteria.

3. Melakukan normalisasi terhadap matriks keputusan menggunakan persamaan (2). Dengan membagikan nilai alternatif dengan nilai total kriteria untuk setiap alternatif.

4. Melakukan optimalisasi kriteria dengan menentukan bobot matriks yang sudah ternomalisasi. Mengurangkan hasil normalisasi terbobot jika kriteria bersifat benefit dengan hasil normalisasi terbobot kriteria bersifat cost.

5. Menentukan rangking alternatif berdasarkan nilai preferensi.

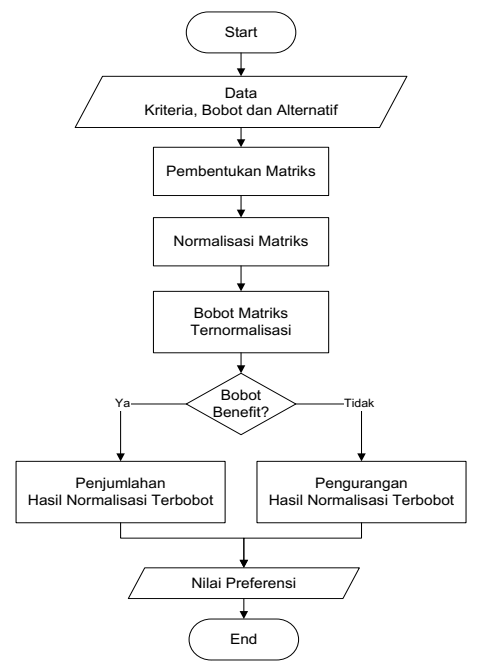

Gambar 1. Alur Algoritma Sistem

\section{Pengumpulan Data}

Data yang digunakan pada penelitian ini diperoleh dengan melakukan identifikasi terhadap kriteria yang digunakan dalam menentukan strategi pemasaran produk pada PT. Universal Gloves. Selain itu, pengumpulan data diperoleh dari karya ilmiah yang berhubungan dengan konten penelitian untuk mencapai hasil penelitian. Data tersebut akan dianalisis menggunakan metode MOORA.

\section{Kriteria}

Aspek kriteria sumber daya pemasaran yang digunakan pada penelitian ini dimana masing-masing aspek kriteria tersebut memiliki kriteria yang disertai 
bobot kepentingan masing-masing. Bobot masingmasing kriteria ditentukan berdasarkan pengaruh dari kriteria tersebut terhadap strategi pemasaran yang akan dipilih.

Tabel 1. Tabel Aspek Kriteria

\begin{tabular}{|l|l|l|}
\hline Kode & Aspek Kriteria & Bobot \\
\hline Kapabilitas Manajerial & \\
\hline K1 & Kondisi Keuangan & 10 \\
\hline K2 & Manajemen SDM yang Efektif & 5 \\
\hline K3 & Manajemen Operasi yang Efisien & 5 \\
\hline Kapabilitas Menjaga Pelanggan & \\
\hline K4 & Layanan Terhadap Pelanggan & 10 \\
\hline K5 & Relasi Dengan Pelanggan & 5 \\
\hline K6 & $\begin{array}{l}\text { Tingkat Pemahaman Terhadap Produk } \\
\text { yang Dibutuhkan Pasar }\end{array}$ & 5 \\
\hline K7 & $\begin{array}{l}\text { Usaha yang Dilakukan Untuk Pelanggan } \\
\text { Sasaran }\end{array}$ & 5 \\
\hline K8 & Pembinaan Relasi dengan Pelanggan & 5 \\
\hline Kapabilitas Berinovasi & \\
\hline K9 & Kapabilitas Membuat Produk yang Baru & 5 \\
\hline K10 & Kapabilitas Produksi yang Efektif & 5 \\
\hline Aset Sumber Daya Manusia & \\
\hline K11 & Tingkat Kepuasan Kerja Karyawan & 5 \\
\hline K12 & Tingkat Retensi Karyawan & 5 \\
\hline Kapabilitas Dalam Distribusi & \\
\hline K13 & Hubungan Dengan Distributor & 5 \\
\hline K14 & Nilai Imbalan yang Didapat Distributor & 5 \\
\hline K15 & Membina Distributor Berprestasi & 5 \\
\hline K16 & $\begin{array}{l}\text { Fasilitas yang Diberikan Kepada } \\
\text { Distributor }\end{array}$ & 5 \\
\hline Reputasi & Reputasi Merk Produk & 5 \\
\hline K17 & Kepercayaan Masyarakat & 5 \\
\hline K18 & & \\
\hline
\end{tabular}

Nilai himpunan kriteria yang diberikan untuk setiap kriteria diatas didasarkan skala kepentingan yang diperoleh secara objektif seperti berikut:

- Bagus $=3$
- Cukup $=2$
- Kurang $=1$

Sedangkan strategi pemasaran sebagai alternatif yang akan dipilih adalah:

Tabel 2. Tabel Alternatif

\begin{tabular}{|c|l|}
\hline Kode & \multicolumn{1}{|c|}{ Alternatif } \\
\hline A1 & Cost Leadership Strategy \\
\hline A2 & Differentiation Strategy \\
\hline A3 & Market Segmentation Strategies \\
\hline
\end{tabular}

\section{HASIL DAN PEMBAHASAN}

\section{Menentukan Nilai Kriteria dari Alternatif}

Nilai alternatif untuk setiap kriteria ditentukan menggunakan skala kepentingan, dimana nilai setiap kriteria diberikan bobot sesuai fakta menurut pihak yang memberikan nilai.

Tabel 3. Nilai Alternatif Untuk Setiap Kriteria

\begin{tabular}{|c|c|c|c|c|c|c|c|c|c|}
\hline \multirow{2}{*}{ Alt } & \multicolumn{10}{|c|}{ Kriteria } \\
\cline { 2 - 10 } & K1 & K2 & K3 & K4 & K5 & K6 & K7 & K8 & K9 \\
\hline A1 & 3 & 3 & 2 & 1 & 2 & 1 & 3 & 2 & 1 \\
\hline A2 & 3 & 1 & 2 & 3 & 3 & 2 & 3 & 2 & 3 \\
\hline A3 & 3 & 2 & 3 & 1 & 1 & 3 & 2 & 3 & 1 \\
\hline
\end{tabular}

(Sambungan Tabel 3)

\begin{tabular}{|c|c|c|c|c|c|c|c|c|c|c|}
\hline \multirow{2}{*}{ Alt } & \multicolumn{10}{|c|}{ Kriteria } \\
\cline { 2 - 10 } & K10 K11 & K12 & K13 & K14 & K15 & K16 & K17 & K18 \\
\hline A1 & 3 & 2 & 2 & 1 & 3 & 2 & 3 & 2 & 3 \\
\hline A2 & 1 & 1 & 3 & 1 & 1 & 3 & 2 & 3 & 1 \\
\hline A3 & 2 & 2 & 2 & 1 & 2 & 3 & 3 & 2 & 2 \\
\hline
\end{tabular}

\section{Matriks Keputusan}

Berdasarkan nilai kriteria seperti tabel diatas maka dapat ditentukan matriks keputusan seperti pada tabel berikut ini:

$$
\begin{aligned}
& \begin{array}{llllllllllll}
3 & 3 & 2 & 1 & 2 & 1 & 3 & 2 & 1 & 3 & 2 & 2
\end{array} \\
& \mathrm{X}=\mid \begin{array}{llllllllllll}
3 & 1 & 2 & 3 & 3 & 2 & 3 & 2 & 3 & 1 & 1 & 3
\end{array} \\
& \begin{array}{llllllllllll}
3 & 2 & 3 & 1 & 1 & 3 & 2 & 3 & 1 & 2 & 2 & 2
\end{array} \\
& \begin{array}{llllll}
1 & 3 & 2 & 3 & 2 & 3
\end{array} \\
& \begin{array}{llllll}
1 & 1 & 3 & 2 & 3 & 1
\end{array} \\
& \begin{array}{llllll}
1 & 2 & 3 & 3 & 2 & 2
\end{array}
\end{aligned}
$$

\begin{tabular}{|c|c|c|c|c|c|c|}
\hline \multirow[b]{2}{*}{ Alt } & \multicolumn{6}{|c|}{ Kriteria } \\
\hline & K1 & K2 & K3 & K4 & K5 & K6 \\
\hline & 0,5773 & 0,8017 & 0,4850 & 0,3015 & 0,5345 & 0,2672 \\
\hline A1 & 5027 & 8373 & 7125 & 1134 & 2248 & 61242 \\
\hline & 0,5773 & 0,2672 & 0,4850 & 0,9045 & 0,8017 & 0,5345 \\
\hline A2 & 5027 & 6124 & 7125 & 3403 & 8373 & 22484 \\
\hline & 0,5773 & 0,5345 & 0,7276 & 0,3015 & 0,2672 & 0,8017 \\
\hline A3 & 5027 & 2248 & 0688 & 1134 & 6124 & 83726 \\
\hline
\end{tabular}

\section{Matriks Normalisasi}

\begin{tabular}{|c|c|c|c|c|c|c|}
\hline \multirow{2}{*}{ Alt } & \multicolumn{6}{|c|}{ Kriteria } \\
\hline & K7 & K8 & K9 & K10 & K11 & K12 \\
\hline \multirow{2}{*}{$\mathrm{A} 1$} & 0,6396 & 0,4850 & 0,3015 & 0,8017 & 0,6666 & 0,4850 \\
\hline & 0215 & 7125 & 1134 & 83726 & 6667 & 7125 \\
\hline \multirow{2}{*}{ A2 } & 0,6396 & 0,4850 & 0,9045 & 0,2672 & 0,3333 & 0,7276 \\
\hline & 0215 & 7125 & 3403 & 61242 & 3333 & 06875 \\
\hline \multirow{2}{*}{ A3 } & 0,4264 & 0,7276 & 0,3015 & 0,5345 & 0,6666 & 0,4850 \\
\hline & 0143 & 0688 & 1134 & 22484 & 6667 & 7125 \\
\hline \multicolumn{7}{|c|}{ Sambungan tabel 4) } \\
\hline \multirow[b]{2}{*}{ Alt } & \multicolumn{6}{|c|}{ Kriteria } \\
\hline & K13 & K14 & K15 & K16 & K17 & K18 \\
\hline \multirow[b]{2}{*}{$\mathrm{A} 1$} & 0,5773 & 0,8017 & 0,4264 & 0,6396 & 0,4850 & 0,8017 \\
\hline & 5027 & 8373 & 0143 & 0215 & 7125 & 83726 \\
\hline \multirow{3}{*}{ A2 } & 0,5773 & 0,2672 & 0,6396 & 0,4264 & 0,7276 & 0,2672 \\
\hline & 5027 & 6124 & 0215 & 0143 & 06875 & 61242 \\
\hline & 0,5773 & 0,5345 & 0,6396 & 0,6396 & 0,4850 & 0,5345 \\
\hline A3 & 5027 & 2248 & 0215 & 0215 & 7125 & 22484 \\
\hline
\end{tabular}

Langkah berikutnya adalah melakukan normalisasi matriks dengan menghitung nilai $\mathrm{X}$ setiap alternatif.

Tabel 4. Matriks Ternormalisasi

\section{Optimalisasi Atribut}

Untuk optimalisasi matriks ternormalisasi dari setiap alternatif, maka dilakukan perkalian bobot alternatif dengan hasil normalisasi untuk tiap kriteria. Berikut ini adalah optimalisasi atribut untuk kriteria yang bersifat menguntungkan (benefit): 


$$
\begin{aligned}
& \mathrm{y}^{*}{ }_{\mathrm{A} 1}=(0,57735027 * 10)+(0,80178373 * 5)+ \\
& (0,48507125 * 5)+(0,30151134 * 10)+ \\
& (0,53452248 * 5)+(0,267261242 * 5)+ \\
& (0,63960215 * 5)+(0,48507125 * 5)+ \\
& (0,30151134 * 5)+(0,801783726 * 5)+ \\
& (0,66666667 * 0.05)+(0,48507125 * 5)+ \\
& (0,57735027 * 5)+(0,80178373 * 5)+ \\
& (0,42640143 * 5)+(0,63960215 * 5)+ \\
& (0,48507125 * 5)+(0,801783726 * 5) \\
& \mathrm{y}^{*}{ }_{\mathrm{A} 1}=\mathbf{5 4 , 7 9 0 3 0 4 3}
\end{aligned}
$$

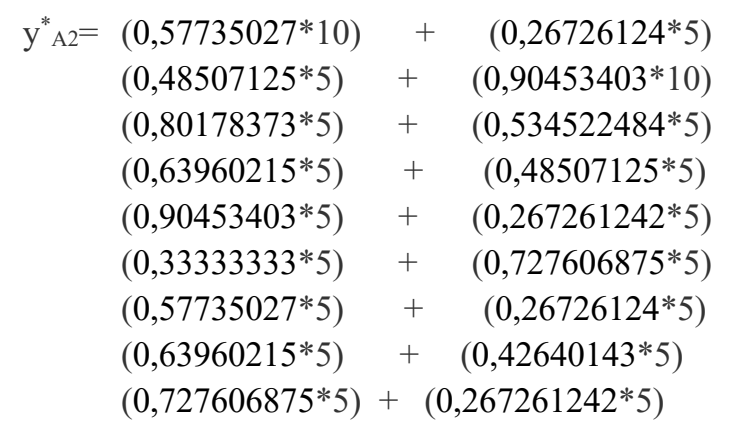

$$
\begin{aligned}
& \mathrm{y}^{*}{ }_{\mathrm{A} 2}=\mathbf{5 6 , 5 7 6 4 9 7}
\end{aligned}
$$

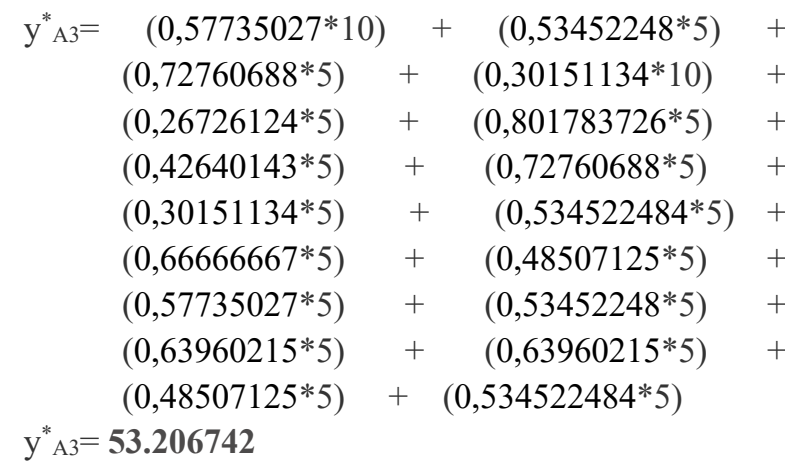

Sedangkan optimalisasi atribut untuk kriteria yang tidak menguntungkan (cost) tidak ada atau dengan kata lain memiliki nilai nol (0). Selanjutnya dilakukan pengurangan antara kriteria yang memiliki atribut benefit dan cost seperti pada tabel berikut:

Tabel 5. Tabel Nilai Preferensi

\begin{tabular}{|c|c|c|c|}
\hline \multirow{3}{*}{ Kode } & $\begin{array}{c}\text { MAX } \\
\text { (K1+K2+K3+K4+K+ } \\
\text { K6+K7+K8+K9+K1+ } \\
\text { K11+K12+K13+K14+ } \\
\text { K15+K16+K17+K18) }\end{array}$ & MIN & $\begin{array}{c}\text { Nilai } \\
\text { (MAX-MIN) }\end{array}$ \\
\hline A1 & 54,790304 & 0 & 54,790304 \\
\hline A2 & 56,576497 & 0 & 56,576497 \\
\hline A3 & 53.206742 & 0 & 53.206742 \\
\hline
\end{tabular}

\section{Nilai Prefrensi}

Nilai preferensi didapat setelah mengurangkan antara total nilai kriteria yang memiliki atribut benefit (max) dengan nilai kriteria yang memiliki atribut cost (min). Berdasarkan nilai preferensi tersebut diperoleh rangking alternatif berupa strategi pemasaran yang akan digunakan perusahaan.

Tabel 6. Ranking

\begin{tabular}{|c|c|c|}
\hline Alternatif & Nilai Preferensi & Rangking \\
\hline $\mathrm{A} 2$ & 56,576497 & 1 \\
\hline $\mathrm{A} 1$ & 54,790304 & 2 \\
\hline $\mathrm{A} 3$ & 53.206742 & 3 \\
\hline
\end{tabular}

Berdasarkan perhitungan diatas, maka strategi pemasaran yang cocok untuk dijalankan adalah A1 yaitu Differentiation Strategy dengan nilai preferensi 56,576497. Sedangkan alternatif strategi pemasaran lainnya yang dapat dilakukan adalah dengan Cost Leadership Strategy dengan nilai preferensi 54,790304. Dan strategi pemasaran Market Segmentation Strategies memiliki nilai preferensi sebesar 53.206742.

\section{KESIMPULAN}

Berdasarkan pembahasan diatas, maka penulis membuat kesimpulan dimana hasil analisis strategi pemasaran produk menggunakan metode MOORA menghasilkan nilai setiap alternatif strategi pemasaran dimana differentiation strategy memiliki nilai preferensi 56,576497, cost leadership strategy dengan nilai 54,790304 dan market segmentation strategies dengan nilai 53.206742. Differentiation strategy dipilih sebagai strategi untuk memasarkan produk perusahaan dengan menciptakan suatu produk yang unik yang tidak dimiliki perusahaan lain karena strategi ini memiliki nilai preferensi yang paling tinggi.

\section{DAFTAR PUSTAKA}

Arvianto, A., Sari, D. P., \& Olivia, G. (2014). Pemilihan Strategi Pemasaran Pada PT. Nyonya Meneer Dengan Menggunakan Pendekatan Metode Analytical Networ Process (ANP) dan Technique For Order Preference By Simalarity To An Ideal Solution (TOPSIS). J@TI UnDip : Jurnal Teknik Industri, 9(3), 35-44.

Budiwaluyo, B. T., \& Setiyaningsih, W. (2015). Sistem Pendukung Keputusan Prediksi Pemasaran Penjualan Mobil Berdasarkan Kebutuhan Pelanggan Dengan Metode Weighted Product. Jurnal Mahasiswa Fakultas Sains Dan Teknologi, 1(1).

Gusman, A. P., Verdian, I., \& Efnita, T. (2017). Fuzzy Logic Dalam Menentukan Strategi Pemasaran Umkm ( Usaha Mikro Kecil Menengah ). Jurnal Teknologi, 7(2), 220-229.

Hakim, M. A., \& Faizah, N. (2018). Analisis Strategi Differensiasi Citra Perusahaan dalam Pemasaran Sebagai Upaya Untuk Menciptakan Keunggulan 
Bersaing ( Studi Pada PT. Ar Tour \& Travel). BISNIS : Jurnal Bisnis Dan Manajemen Islam, $5(2), 383$.

Hasanah, T., Parlina, I., \& S.Sitio, H. J. (2019). Sistem Pendukung Keputusan Pemilihan Jurusan Pada Yayasan Muhammad Nasir dengan Menggunakan Metode MOORA. Journal of Informatics and Telecommunication Engineering, 2(2), 128.

Hernanti, S. B. P., Waluyo, D. E., \& Izzhati, D. N. (2017). Pengambilan Keputusan Strategi Pemasaran Terbaik pada PT. Astra International TBK. UD Truck SO Cabang Semarang. Applied Industrial Engineering Journal, 1(Vol 1, No 2 (2017)), 15-23.

Jannah, M. (2014). Strategi Inovasi Produk Dalam Mencapai Keunggulan Kompetitif. ISLAMICONOMIC: Jurnal Ekonomi Islam, 5(1), 1-15. https://doi.org/10.32678/ijei.v5i1.20

Manurung, S. (2018). Sistem Pendukung Keputusan Pemilihan Guru Dan Pegawai Terbaik Menggunakan Metode Moora. Simetris: Jurnal Teknik Mesin, Elektro Dan Ilmu Komputer, 9(1), 701-706.

Mayang Sari, P. R., Santoso, P. B., \& Hamdala, I. (2014). Pengambilan Keputusan Strategi Pemasaran Menggunakan Metode ANP dan Fuzzy TOPSIS (Studi Kasus : PT X Mojokerto). Jurnal Rekayasa Dan Manajemen Sistem Industri, 2(2), 428-437.

Sianturi, S. (2015). Sistem Pendukung Keputusan Penentuan Kebijakan Strategi Promosi Kampus Dengan Metode Profile Matching. Pelita Informatika Budi Darma, 9(2), 60-68.

Sugiarti, S., Nahulae, D. K., Syafrizal, Panggabean, T. E., \& Sianturi, M. (2018). Sistem Pendukung Keputusan Penentuan Kebijakan Strategi Promosi Kampus Dengan Metode Weighted Aggregated Sum Product Assesment (WASPAS). JURIKOM (Jurnal Riset Komputer), 5(2), 103-108.

Utsalina, D. S., \& Dewa, W. A. (2015). Strategi Pemasaran Menggunakan Metode Kombinasi SWOT Dan AHP (Studi Kasus : STMIK Pradnya Paramita). SMATIKA Jurnal, 05(2), 1826.

Wardani, S., Parlina, I., \& Revi, A. (2018). Analisis Perhitungan Metode MOORA dalam Pemilihan Supplier Bahan Bangunan di Toko Megah Gracindo Jaya. InfoTekJar (Jurnal Nasional Informatika Dan Teknologi Jaringan), 3(1), 9599. 